\title{
Cerebellar astrocytoma: experience with 54 cases surgically treated at the Mayo Clinic, Rochester, Minnesota from 1978 to 1990
}

Vittorio M. Morreale, M.D., Michael J. Ebersold, M.D., Lynn M. Quast, R.N., B.S.N., and Joseph E. Parisi, M.D.

Department of Neurologic Surgery, Mayo Graduate School of Medicine, and Departments of Laboratory Medicine, Pathology, and Neurology, Mayo Clinic, Rochester, Minnesota

A comprehensive review of the literature has shown that the treatment of choice for cerebellar astrocytomas has primarily been gross-total resection of the mass and gross-total resection of the enhancing portion of pilocytic astrocytomas. Most large scale studies of postresection survival rates of patients with cerebellar astrocytomas were conducted when computerized tomography (CT) or magnetic resonance (MR) imaging was not readily available. It has been shown that postoperative CT scans or MR images are more reliable than the surgeon's estimate of the degree of tumor resection at the time of surgery. It is not possible, therefore, to make an accurate determination regarding a postresection prognosis based on the degree of suspected tumor resection without the availability of appropriate radiographic imaging. In this study, the authors retrospectively evaluated the treatment of 54 patients with cerebellar astrocytoma who underwent surgery at the Mayo Clinic in Rochester, Minnesota from 1978 through 1990. Preoperative and postoperative CT scans or MR images were available in all 54 patients.

Key Words * cerebellar astrocytoma * prognosis * survival * treatment * pilocytic astrocytoma * radiology

Cerebellar astrocytomas represent $3.5 \%$ of all primary intracranial brain tumors,[24] $10 \%$ of pediatric primary intracranial brain tumors,[35] approximately $25 \%$ of pediatric posterior fossa brain tumors,[2,31,35] and $8 \%$ of gliomas.[22] It is generally accepted that appropriate treatment of cerebellar astrocytomas consists of complete resection.[19,24] Although the rates of morbidity and mortality after resection vary, they have improved in recent years.[7,24] Survival length has been shown to be dependent on the degree of tumor resection and the tumor histology.[3,12,13,15,18] The postoperative recurrence rate has been reported to be very low and, according to some authors, approaches 0\%.[24] Cushing[9] advocated complete tumor removal, including resection of the nodular component of a cystic cerebellar astrocytoma and drainage of the cyst. Using this approach, he achieved good operative results and low rates of recurrence. Nevertheless, there are many reports of tumor recurrence after presumed complete resection. $[6,26,29,33]$ It has been shown that the degree of tumor resection that is determined by the surgeon intraoperatively does not always correlate with the actual amount of tumor resection that is demonstrated on postoperative computerized tomography (CT) or magnetic resonance (MR) imaging.[28] Because many large studies of the treatment of cerebellar astrocytomas include periods of 
time that antedate neuroimaging,[5,10,11,14,16,17,22,31,32] prognostication on the basis of these studies cannot be accurate when the degree of tumor resection was ambiguous. In this study, we retrospectively reviewed the outcome of patients with cerebellar astrocytomas who were treated during a period of time when reliable $\mathrm{CT}$ and/or MR imaging was available.

\section{CLINICAL MATERIAL AND METHODS}

\section{Patient Population}

A retrospective analysis was performed on the clinical records of 54 patients surgically treated for cerebellar astrocytoma. All of their surgical procedures were performed at the Mayo Clinic in Rochester, Minnesota. A complete neurological evaluation was performed by both a neurosurgeon and neurologist, pre- and postoperatively, in all patients. Patients were excluded from the analysis if they had received prior therapy. Follow-up review of cases was conducted through a combination of phone calls and mailed questionnaires.

The time frame of 1978 to 1990 was chosen to assure that reasonable-quality radiographic imaging and maximum follow-up review were available.

\section{Pathological Considerations}

In all cases, the tumors were primary astrocytomas of the cerebellum. Patients were excluded if, at the time of surgery, the tumor was determined to have originated elsewhere, such as in a cerebellar peduncle or cerebellopontine angle as an exophytic mass. Such groups of patients represent diagnostic groups that are different from patients with more narrowly defined cerebellar astrocytomas. The original slides of the tumor specimens were reviewed by a neuropathologist (J.E.P.) who was unaware of the original histological diagnosis.

\section{Preoperative Imaging}

All patients had undergone preoperative imaging which included either CT scanning with contrast enhancement or MR imaging with or without addition of gadolinium. Some patients also had undergone angiography.

\section{RESULTS}

\section{Patient Demographics}

The patients' ages ranged from 1 to 80 years with a mean age of 26 years. Half of the patients were less than 15 years old, and $75 \%$ of the patients were less than 40 years old. There was a bimodal age distribution, with a younger age group occurring between 1 and 15 years with a mean age of 7 years (27 patients) and an older age group between 50 to 80 years with a mean age of 64 years (13 patients). Fourteen patients were of intermediate age: ranging from 16 to 40 years old with a mean age of 27 years (Fig. 1). 


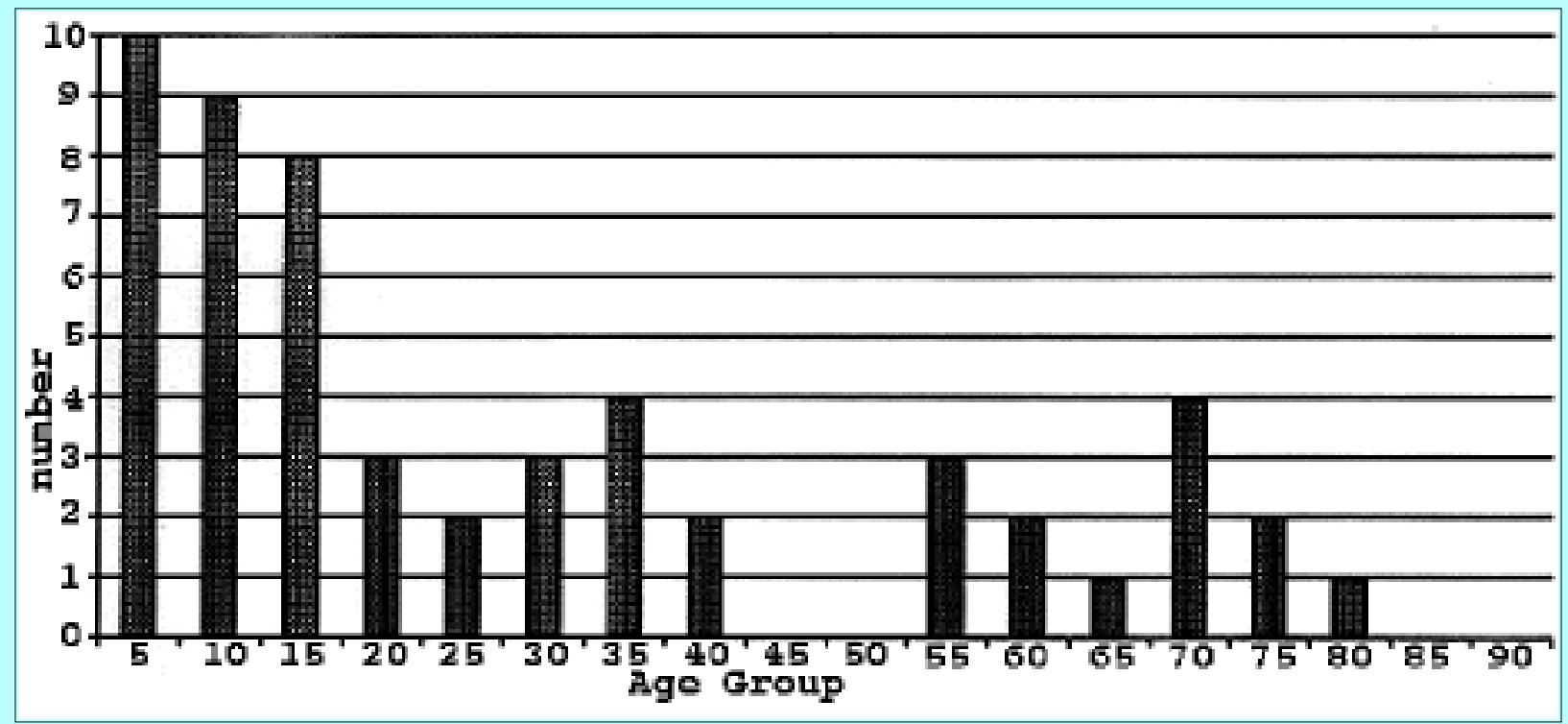

Fig. 1. Histogram representing the age distribution of patients in the study.

There were 26 males (48\%) and 28 females (52\%) in the study. In the 1- to 15-year-old age group, there were 11 boys ( $41 \%$ ) and 16 girls (59\%); in the 16- to 40 -year-old age group, there were seven males $((50 \%)$ and seven females $(50 \%)$; and in the 50 years of age and over group, there were eight men (62\%), and five women $(38 \%)$.

\section{Pathological Considerations}

The distribution of tumor pathology in the group consisted of 39 cases of pilocytic astrocytoma (72\%), two cases of low-grade diffusely infiltrating (nonpilocytic) fibrillary astrocytoma (4\%), three cases of Grade III astrocytoma (6\%), nine cases of Grade IV astrocytoma (17\%), and one case of gliosarcoma (2\%). Pilocytic astrocytomas were more prevalent in the young age group. High-grade diffuse astrocytomas were approximately evenly distributed throughout all age groups. Table 1 shows the distribution of tumor types according to patient age. 


\begin{tabular}{|c|c|c|c|c|c|c|}
\hline \multicolumn{7}{|c|}{$\begin{array}{c}\text { TABLE } 1 \\
\text { DISTRIBUTION OF TUMOR PATHOLOGY BV AGE GROUP IN } 54 \text { PATIENTS WITH } \\
\text { CEREBELLER ASTROCVTOMA }\end{array}$} \\
\hline $\begin{array}{c}\text { Age } \\
\text { Group (yrs) }\end{array}$ & Pilocyic & $\begin{array}{l}\text { Low' } \\
\text { Grade }\end{array}$ & $\begin{array}{c}\text { Grade } \\
\text { III }\end{array}$ & $\begin{array}{c}\text { Grade } \\
\mid Y\end{array}$ & $\begin{array}{c}\text { Glio- } \\
\text { sarcona }\end{array}$ & Totals \\
\hline $0-5$ & 9 & 1 & 0 & 0 & 0 & 10 \\
\hline $6-10$ & 8 & 0 & 0 & 1 & 0 & 9 \\
\hline $11-15$ & 8 & 0 & 0 & 0 & 0 & 8 \\
\hline $16-20$ & 3 & 0 & 0 & 0 & 0 & 3 \\
\hline $21-25$ & 2 & 0 & 0 & 0 & 0 & 2 \\
\hline $26-30$ & 3 & 0 & 0 & 0 & 0 & 3 \\
\hline $31-35$ & 3 & 0 & 0 & 1 & 0 & 4 \\
\hline $36-40$ & 0 & 0 & 0 & 2 & 0 & 2 \\
\hline $41-45$ & 0 & 0 & 0 & $\overline{0}$ & 0 & $\overline{0}$ \\
\hline $46-50$ & 0 & 0 & 0 & 0 & 0 & 0 \\
\hline $51-55$ & 0 & 0 & 1 & 1 & 1 & 3 \\
\hline $56-60$ & 2 & 0 & 0 & 0 & 0 & 2 \\
\hline $61-65$ & 0 & 1 & 0 & 0 & 0 & 1 \\
\hline $66-70$ & 1 & 0 & 1 & 2 & 0 & 4 \\
\hline $71-75$ & 0 & 0 & 1 & 1 & 0 & 2 \\
\hline $76-80$ & 0 & 0 & 0 & 1 & 0 & 1 \\
\hline$>80$ & 0 & 0 & 0 & 0 & 0 & 0 \\
\hline all ages & 39 & 2 & 3 & 9 & 1 & 54 \\
\hline
\end{tabular}

\section{Presenting Symptoms and Signs}

The most common presenting symptoms were headache, nausea, vomiting, gait ataxia, arm ataxia, weakness, diplopia, and dizziness. Objective signs included weakness, long tract signs, arm and leg ataxia, and nystagmus. Table 2 lists the frequency of presenting signs and symptoms. The average Karnofsky Performance Scale[20] score at presentation was 81 for all groups combined. Patients with pilocytic astrocytomas had an average Karnofsky Performance Scale score of 86 at presentation, whereas patients with diffuse astrocytomas had an average score of 80.

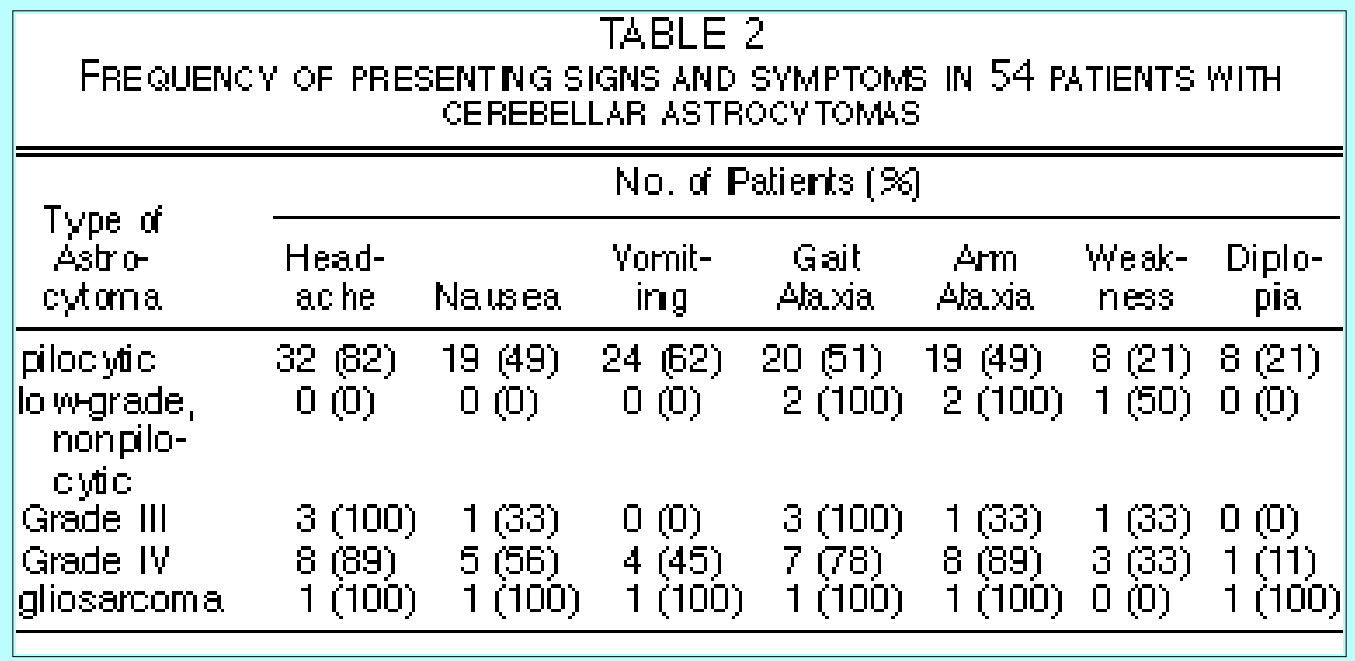

\section{Imaging Studies}

Fifty-three patients had undergone preoperative CT scanning without contrast enhancement and 49 patients CT scanning with contrast enhancement. Three patients had undergone MR imaging with and without addition of gadolinium. Forty of 49 tumors enhanced when CT studies were performed using contrast agents. Two of three tumors enhanced when gadolinium was added for MR imaging. Table 3 
shows the enhanced imaging characteristics in patients according to tumor type. Thirty-two patients underwent preoperative angiography.

\begin{tabular}{|c|c|c|c|c|c|c|}
\hline \multicolumn{7}{|c|}{$\begin{array}{c}\text { TABLE } 3 \\
\text { CHARACTERISTICS AND FIND NGS ON PREOPERATNE CONTRAST-ENHANCED NEU- } \\
\text { ROIMGGING IN } 54 \text { PATIENTS WITH CEREBELLAR ASTROCYTOMAS } \\
\end{array}$} \\
\hline \multirow[b]{2}{*}{$\begin{array}{c}\text { Type of } \\
\text { Astrocytoma }\end{array}$} & \multicolumn{2}{|c|}{$\begin{array}{c}\text { Cases WI } \\
\text { CT Scanning }\end{array}$} & \multicolumn{2}{|c|}{$\begin{array}{l}\text { Cases WI } \\
\text { MR Imaging }\end{array}$} & \multirow[b]{2}{*}{$\begin{array}{c}\text { No. of } \\
\text { Tunors Wh } \\
\text { Hydrocep } \mathrm{H} \\
\text { alus }(\%)\end{array}$} & \multirow[b]{2}{*}{$\begin{array}{l}\text { No. of } \\
\text { Cystic } \\
\text { Tumors } \\
(\%)^{*}\end{array}$} \\
\hline & $\begin{array}{l}\text { Total } \\
\text { No. }\end{array}$ & $\begin{array}{l}\text { No. of } \\
\text { Enhanc ed } \\
\text { Tum ors }[\%]\end{array}$ & $\begin{array}{l}\text { Total } \\
\text { No. }\end{array}$ & $\begin{array}{l}\text { No. of } \\
\text { Enhanc ed } \\
\text { Tum ars }(\%)\end{array}$ & & \\
\hline $\begin{array}{l}\text { pilocytic } \\
\text { lo whgrade, } \\
\text { noncilocitic }\end{array}$ & $\begin{array}{r}35 \\
2\end{array}$ & $\begin{array}{r}28(80) \\
1(50)\end{array}$ & $\begin{array}{l}2 \\
0\end{array}$ & $\begin{array}{l}1(50) \\
0(0)\end{array}$ & $\begin{array}{r}32(82) \\
1(50)\end{array}$ & $\begin{array}{c}33(85) \\
0(0)\end{array}$ \\
\hline $\begin{array}{l}\text { Grade III } \\
\text { Grade IV } \\
\text { gliosarcoma }\end{array}$ & $\begin{array}{l}3 \\
8 \\
1\end{array}$ & $\begin{array}{l}3(100) \\
7(88) \\
1(100)\end{array}$ & $\begin{array}{l}1 \\
0 \\
0\end{array}$ & $\begin{array}{l}1(100) \\
0(0) \\
0(0)\end{array}$ & & $\begin{array}{l}1(33) \\
2(22) \\
1(100)\end{array}$ \\
\hline
\end{tabular}

Table 4 shows the distribution of tumor locations. There did not seem to be any predilection for a particular portion of the cerebellum on the part of any particular tumor type. Two pilocytic astrocytomas and the low-grade nonpilocytic astrocytomas extended into the fourth ventricle.

\begin{tabular}{|c|c|c|c|c|c|}
\hline \multicolumn{6}{|c|}{$\begin{array}{c}\text { TABLE } 4 \\
\text { CEREBELLAR LOCATIONS ACCORDNG TO TUMOR TVPE IN } 54 \text { PATIENTS } \\
\text { WITH ASTROCV TOMAS }\end{array}$} \\
\hline $\begin{array}{c}\text { Type of } \\
\text { Astrocytoma }\end{array}$ & $\begin{array}{l}\text { Lt Heni- } \\
\text { phere }\end{array}$ & $\begin{array}{l}\text { Rt Hemi- } \\
\text { sphere }\end{array}$ & Midine & $\begin{array}{l}\text { Fourth } \\
\text { Vermis }\end{array}$ & Vertricle \\
\hline pilocytic & 14 & 11 & 12 & 17 & 2 \\
\hline $\begin{array}{l}\text { lo whgrade, } \\
\text { nonpilocytic }\end{array}$ & 1 & 1 & 1 & 1 & 1 \\
\hline Grade III & 2 & 1 & 2 & 1 & 0 \\
\hline Grade IV & 3 & 7 & 1 & 1 & 0 \\
\hline gliosarcoma & 1 & 0 & 0 & 0 & 0 \\
\hline
\end{tabular}

Thirty-three (85\%) of 39 pilocytic tumors were cystic. Of the diffuse fibrillary tumors, one Grade III and two Grade IV astrocytomas and the one gliosarcoma presented as a solid mass. Hydrocephalus was evident in 32 pilocytic astrocytomas, one low-grade nonpilocytic astrocytoma, and four high-grade fibrillary astrocytomas (three Grade IV astrocytomas and one gliosarcoma).

\section{Treatment of Patients}

Surgical Outcomes. Overall actual gross-total tumor removal, as documented by postoperative imaging, was achieved in $35(65 \%)$ cases (Table 5). Review of the operative reports of all tumors showed that the surgeon estimated gross-total removal in 34 cases. Occasionally, the interface between tumor and surrounding brain was rather indistinct. This often made it difficult for the surgeon to be confident about whether complete removal was accomplished. There were instances in which the surgeon believed that gross-total removal had been achieved when in fact there was residual tumor and instances in which the surgeon assumed subtotal removal when postoperative imaging showed no tumor. Overall, gross-total removal usually was possible when the tumor was a pilocytic astrocytoma. In the one case of gliosarcoma, postoperative imaging revealed no grossly apparent tumor; however, this patient eventually 
had a recurrence.

\begin{tabular}{|c|c|c|c|c|}
\hline \multirow[b]{3}{*}{$\begin{array}{c}\text { Type of } \\
\text { Astroctoma }\end{array}$} & $\begin{array}{l}\text { OF SURGERV BV } \\
\text { CEREBELL. }\end{array}$ & $\begin{array}{l}\text { SLE } 5 \\
\text { MOR TVPE Ir } \\
\text { ASTROCVTO }\end{array}$ & 4 PATIENT & \\
\hline & \multirow{2}{*}{$\begin{array}{l}\text { Surgeon's Esti- } \\
\text { mate of Gross- } \\
\text { Total Removal }\end{array}$} & \multicolumn{3}{|c|}{ Rad dogcally Cortim ed } \\
\hline & & $\begin{array}{c}\text { Gross-Total } \\
\text { Removal }\end{array}$ & $\begin{array}{l}\text { Residual } \\
\operatorname{Tum} \alpha\end{array}$ & $\begin{array}{c}\operatorname{Tum} \alpha \\
\text { Recurrence }\end{array}$ \\
\hline pilocytic & 29 & 30 & 9 & 2 \\
\hline $\begin{array}{l}\text { Io mgrade, } \\
\text { nonpilocytic }\end{array}$ & 1 & 2 & 0 & 0 \\
\hline Grade III & 1 & 1 & 2 & 1 \\
\hline Grade IV & 2 & 1 & 8 & 0 \\
\hline gliosarcoma & 1 & 1 & 0 & 1 \\
\hline totals & 34 & 35 & 19 & 4 \\
\hline
\end{tabular}

Nineteen patients had residual tumor and four patients had true tumor recurrence as documented by postoperative images (Table 5). Of the patients with residual tumor, two with pilocytic astrocytoma and one with Grade IV astrocytoma underwent surgery within 1 year, and one patient with pilocytic astrocytoma underwent surgery after 1 year. Of the patients who experienced tumor recurrence, two patients with pilocytic astrocytoma underwent surgery after 1 year; the one patient with gliosarcoma and one with Grade III astrocytoma died of tumor progression at 0.8 and 4.1 years postoperatively, respectively.

Adjunctive Therapy. Radiation therapy was administered to six (15\%) of 39 patients with pilocytic astrocytomas, one (50\%) of two patients with low-grade nonpilocytic diffuse fibrillary astrocytomas, all three patients $(100 \%)$ with Grade III astrocytomas, four (44\%) of nine patients with Grade IV astrocytomas, and the one patient (100\%) with a gliosarcoma. In general, the patients in whom tumors were more infiltrative received postoperative radiation therapy because more aggressive surgery was not feasible when the tumor was invasive. One patient with Grade IV astrocytoma did not live long enough after surgery to begin radiation therapy.

Chemotherapy was administered to patients with Grade III astrocytoma as well as the one with gliosarcoma.

Ventriculostomy was required preoperatively in four (10\%) of 39 patients with pilocytic astrocytomas. In one of these patients, ventriculostomy was performed emergently because of acute neurological deterioration. 


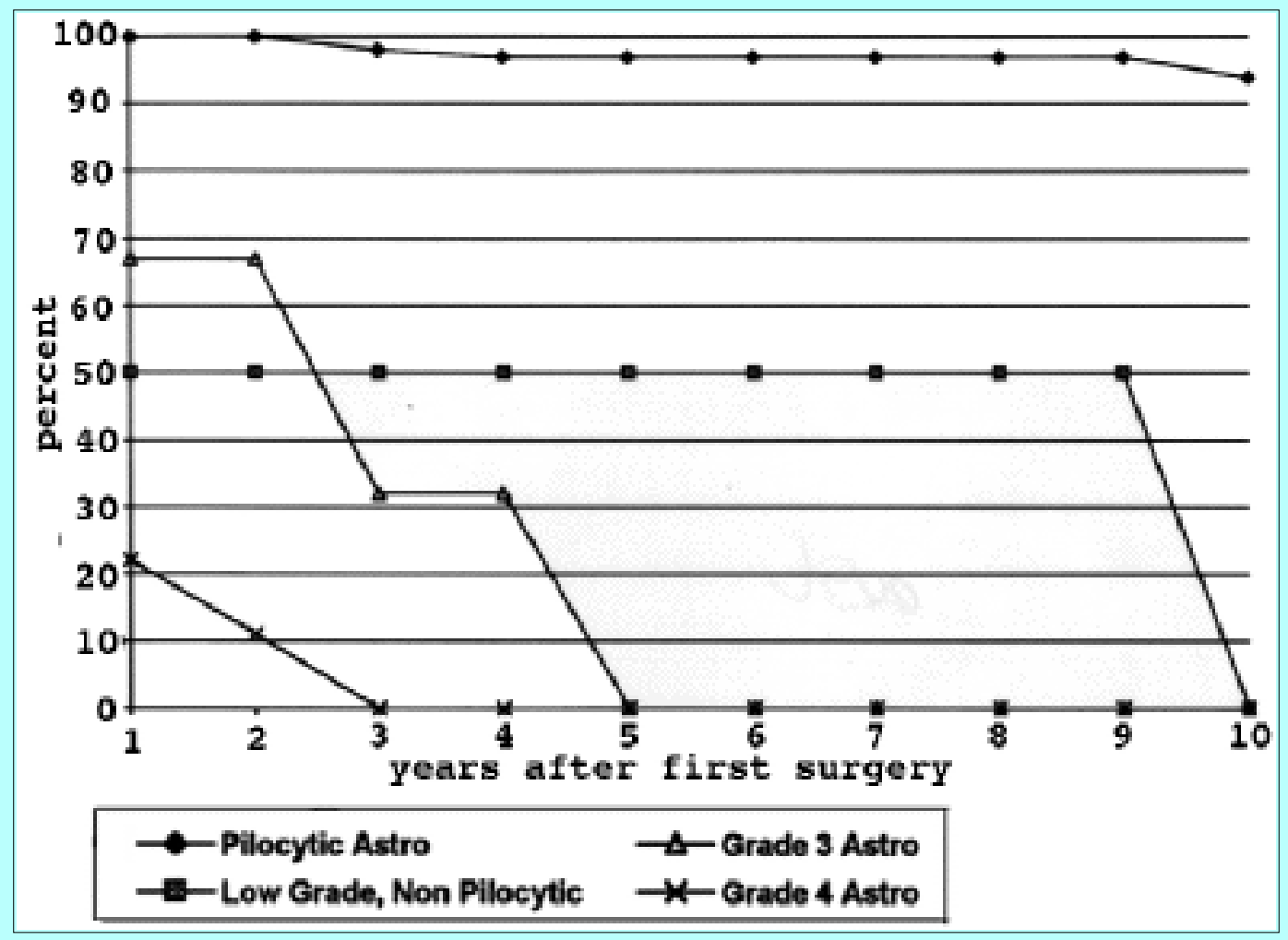

Fig. 2. Graph showing percentage survival at various years after the first surgery. (The patient with a gliosarcoma survived only 0.8 years and is therefore not represented.)

Lengths of Survival. In general, length of survival (Fig. 2) was most dependent on tumor pathology and patient age at presentation (Table 6). Patients with postoperative image-documented gross-total removal had better 1-, 5-, and 10-year survival rates than patients with subtotal tumor resection. There was a 100\% 10-year survival rate in patients who had tumor recurrence and underwent a second operation. Radiation therapy did not significantly affect survival length in patients, regardless of tumor type (Table 7). 
TABLE 6

AVERAGE LENGTHS OF SURVMAL BV TUMOR TVPEAND AGE IN 54 PATIENTS WITH CEREBELLAR ASTROCV TOMA *

\begin{tabular}{|c|c|c|}
\hline $\begin{array}{c}\text { Type of } \\
\text { Astrocytoma }\end{array}$ & $\begin{array}{l}\text { Avera ge Length } \\
\text { of Survival (yrs) }\end{array}$ & $\begin{array}{c}\text { Standard } \\
\text { Deviation (yrs) }\end{array}$ \\
\hline pilocytic & 9.6 & - \\
\hline $\begin{array}{l}\text { lo whgrade, } \\
\text { nonpilocytic }\end{array}$ & 2.9 & - \\
\hline Grade III & 2.3 & - \\
\hline Grade IV & 0.8 & - \\
\hline $\begin{array}{l}\text { gliosarcoma } \\
\text { age group }\end{array}$ & 0.8 & - \\
\hline $0-10$ & 8.5 & 3.8 \\
\hline $11-20$ & 10.1 & 4.1 \\
\hline $21-30$ & 9.1 & 3.6 \\
\hline $31-40$ & 8.2 & 8.0 \\
\hline $41-50$ & NA & NA \\
\hline $51-60$ & 3.3 & 3.4 \\
\hline $61-70$ & 1.8 & 2.1 \\
\hline $71-80$ & 0.2 & 0.2 \\
\hline
\end{tabular}

"NÁ = not applicable (no patient in category); - = not given (num ber of patients in three of five tumor groups mas too small to make standard de viation sufficiently significant).

\begin{tabular}{|c|c|c|c|c|c|c|}
\hline $\mathrm{Com}$ & $\begin{array}{r}\text { ARISON OF } \\
\text { CER }\end{array}$ & $\begin{array}{r}\text { TABL } \\
\text { SURVNAL } \\
\text { BRRAL AST }\end{array}$ & $\begin{array}{l}7 \\
\text { MES IN } 5 \\
\text { OCV TOM }\end{array}$ & 4 PATIEN & TS WITH & \\
\hline $\begin{array}{l}\text { Survival Time } \\
\text { \& Type of } \\
\text { Astrocytoma }\end{array}$ & $\begin{array}{l}\text { Residual } \\
\text { Tumor } \\
{[\%] \dagger}\end{array}$ & $\begin{array}{c}\text { No } \\
\text { Residual } \\
\text { Tumor } \\
{[\%] \dagger}\end{array}$ & $\begin{array}{l}\text { Recur- } \\
\text { rence } \\
\text { (\%) }\end{array}$ & $\begin{array}{c}\text { No } \\
\text { Recu- } \\
\text { rence } \\
{[\%]}\end{array}$ & $\begin{array}{c}\text { Radation } \\
\text { Therapy } \\
\text { (\%) }\end{array}$ & $\begin{array}{c}\text { No } \\
\text { Padation } \\
\text { Therapy } \\
\text { (\%) }\end{array}$ \\
\hline 1-yr sur'vi wal time & & & & & & \\
\hline $\begin{array}{l}\text { pilocytic } \\
\text { lo whgrade, } \\
\text { nonpilocytic }\end{array}$ & $\begin{array}{r}100 \\
0\end{array}$ & $\begin{array}{r}100 \\
50\end{array}$ & $\frac{100}{-}$ & $\begin{array}{r}100 \\
50\end{array}$ & $\begin{array}{r}100 \\
0\end{array}$ & $\begin{array}{l}100 \\
100\end{array}$ \\
\hline Grade III & 50 & 0 & 100 & - & 67 & 0 \\
\hline $\begin{array}{l}\text { Grade IV } \\
\text { gliosarcoma }\end{array}$ & $\begin{array}{c}12.5 \\
0\end{array}$ & $\begin{array}{r}100 \\
0\end{array}$ & $\overline{-}$ & $\frac{100}{-}$ & $\begin{array}{r}25 \\
0\end{array}$ & $\begin{array}{r}20 \\
0\end{array}$ \\
\hline 5-yr survid tel time & & & & & & \\
\hline pilocytic & 87.5 & 100 & 100 & 100 & 100 & 96 \\
\hline $\begin{array}{l}\text { lo whgrade, } \\
\text { nonpilocytic }\end{array}$ & 0 & 50 & - & 50 & 0 & 100 \\
\hline Grade III & 0 & 0 & 0 & - & 0 & 0 \\
\hline Grade IV & 0 & 0 & - & 0 & 0 & 0 \\
\hline gliosarcoma & 0 & 0 & 0 & - & 0 & 0 \\
\hline 10-yr sur wival tim & & & & & & \\
\hline pilocytic & 50 & 100 & - & 100 & 100 & 93 \\
\hline $\begin{array}{l}\text { lo whrgrade, } \\
\text { nonpilocytic }\end{array}$ & 0 & 0 & - & - & 0 & 0 \\
\hline Grade III & 0 & 0 & 0 & - & 0 & 0 \\
\hline Grade IV & 0 & 0 & - & 0 & 0 & 0 \\
\hline gliosarcoma & 0 & 0 & 0 & - & 0 & 0 \\
\hline
\end{tabular}

\section{DISCUSSION}

The results of this study indicate that the most important factor in survival length in patients with 
cerebellar astrocytoma is tumor pathology. Overall, patients with pilocytic astrocytomas survive the longest. It is interesting that patients with documented residual tumor had such high 5- and 10-year survival rates. This is most likely the result of the benign nature of pilocytic astrocytomas. Low-grade and cystic astrocytomas have been shown to have slow growth potential.[21] One could argue that tumor debulking yields the same effect as gross-total removal, which may be an important factor in tumor treatment in eloquent areas of the posterior fossa. However, there are numerous case reports of malignant recurrence of tumor in cases of previous low-grade cerebellar astrocytoma, as long as 30 or more years later.[30] In these reports, proper intracranial imaging was not available, so it is not possible to assess whether these cases were true recurrences or whether they were progressions with malignant transformation of tumor. As others have indicated, follow-up imaging is imperative in the postoperative management of patients with cerebellar astrocytoma.[19]

The fact that younger patients survive longer may be due to a higher incidence of pilocytic astrocytomas in these patients. As has been shown for other tumor types, younger patients generally fare better. Older patients tended to have high-grade, diffuse, and infiltrating tumors, which are not completely resectable and carry a worse prognosis.

Radiation therapy was not found to be of any substantial benefit in this review, although in a few patients with high-grade tumors some benefit may have been realized. Radiation therapy was used to treat all tumor types during the early years of the study, but in later years it was used only in patients with high-grade tumors.

Experiences gleaned from the literature and these data do not support a need for, or benefit of, radiation therapy in treating any posterior fossa astrocytoma, although some reviews have demonstrated therapeutic benefits, especially in cases of higher-grade posterior fossa astrocytomas.[1,4,8,10,12,23,25] Radiation therapy is not without risk: there are case reports of malignant astrocytomas developing many years after radiation therapy in patients who had low-grade astrocytomas, [27,34] and the late development of meningiomas in the radiation field of treatment has also been observed at the Mayo Clinic at Rochester.

In conclusion, the optimum treatment for pilocytic astrocytoma is gross-total resection, whenever possible. Even if gross-total removal cannot be accomplished, often long symptom-free intervals following debulking of pilocytic and low-grade astrocytomas do occur. The role of postoperative radiotherapy in these cases is poorly supported, although the number of patients with higher-grade tumors is small. As Cushing[9] described over 60 years ago, the treatment of choice for the low-grade cystic astrocytomas is total removal of the solid nodule of tumor and drainage of the cyst.

\section{References}

1. Akyol FH, Atahan IL, Zorlu F, et al: Results of post-operative or exclusive radiotherapy in grade I and grade II cerebellar astrocytoma patients. Radiother Oncol 23:245-248, 1992

2. American Association of Neurological Surgeons (eds): Pediatric Neurosurgery. Surgery of the Developing Nervous System, ed 1. New York: Grune \& Stratton, 1982, pp 367-374

3. Ampil FL: Prognostic factors in childhood intracranial neoplasms. Radiat Med 5:202-206, 1987

4. Austin EJ, Alvord EC Jr: Recurrences of cerebellar astrocytomas: a violation of Collins' law. J 
Neurosurg 68:41-47, 1988

5. Bucy PC, Thieman PW: Astrocytomas of the cerebellum. A study of a series of patients operated upon over 28 years ago. Arch Neurol 18:14-19, 1968

6. Casadei GP, Arrigoni GL, D'Angelo V, et al: Late malignant recurrence of childhood cerebellar astrocytoma. Clin Neuropathol 9:295-298, 1990

7. Cochrane DD, Gustavsson B, Poskitt KP, et al: The surgical and natural morbidity of aggressive resection for posterior fossa tumors in childhood. Pediatr Neurosurg 20:19-29, 1994

8. Conway PD, Oechler HW, Kun LE, et al: Importance of histologic condition and treatment of pediatric cerebellar astrocytoma. Cancer 67:2772-2775, 1991

9. Cushing H: Experiences with cerebellar astrocytoma. A critical review of seventy-six cases. Surg Gynecol Obstet 52:129-204, 1931

10. Ferbert A, Gullotta F: Remarks on the follow-up of cerebellar astrocytomas. J Neurol 232:134-136, 1985

11. Garcia DM, Latifi HR, Simpson JR, et al: Astrocytomas of the cerebellum in children. J Neurosurg 71:661-664, 1989

12. Garcia DM, Marks JE, Latifi HR, et al: Childhood cerebellar astrocytomas: is there a role for postoperative irradiation? Int J Radiat Oncol Biol Phys 18:815-818, 1990

13. Gjerris F, Klinken L: Long-term prognosis in children with benign cerebellar astrocytoma. J Neurosurg 49:179-184, 1978

14. Griffin TW, Beaufait D, Blasko JC: Cystic cerebellar astrocytomas in childhood. Cancer 44:276-280, 1979

15. Hayostek CJ, Shaw EG, Scheithauer B, et al: Astrocytomas of the cerebellum. A comparative clinicopathologic study of pilocytic and diffuse astrocytomas. Cancer 72:856-869, 1993

16 Heiskanen O, Lehtosalo J: Surgery of cerebellar astrocytomas, ependymomas, and medulloblastomas in children. Acta Neurochir 78:1-3, 1985

17. Ilgren EB, Stiller CA: Cerebellar astrocytomas. Clinical characteristics and prognostic indices. J Neurooncol 4:293-308, 1987

18. Ilgren EB, Stiller CA: Cerebellar astrocytomas. Part II. Pathologic features indicative of malignancy. Clin Neuropathol 6:201-214, 1987

19. Ilgren EB, Stiller CA: Cerebellar astrocytomas: therapeutic management. Acta Neurochir 81:11-26, 1986

20. Karnofsky DA, Burchenal JH: The clinical evaluation of chemotherapeutic agents in cancer, in MacLeod CM (ed): Evaluation of Chemotherapeutic Agents. New York: Columbia University Press, 1949, pp 191-205

21. Kepes JJ, Whittaker CK, Watson K, et al: Cerebellar astrocytomas in elderly patients with very long 
preoperative histories: report of three cases. Neurosurgery 25:258-264, 1989

22. Kibirige MS, Birch JM, Campbell RH, et al: A review of astrocytoma in childhood. Pediatr Hematol Oncol 6:319-329, 1989

23. Lapras C, Patet JD, Lapras C Jr, et al: Cerebellar astrocytomas in childhood. Childs Nerv Syst 2:55-59, 1986

24. Obrador S, Blazquez MG: Benign cystic tumours of the cerebellum. Acta Neurochir 32:55-68, 1975 25. Onoyama Y, Abe M, Takahashi M, et al: Radiation therapy of brain tumors in children. Radiology 115:687-693, 1975

26. Pagni CA, Giordana MT, Canavero S: Benign recurrence of a pilocytic cerebellar astrocytoma 36 years after radical removal: case report. Neurosurgery 28:606-609, 1991

27. Rappaport ZH, Loven D, Ben-Aharon U: Radiation-induced cerebellar glioblastoma multiforme subsequent to treatment of an astrocytoma of the cervical spinal cord. Neurosurgery 29:606-608, 1991

28. Schneider JH Jr, Raffel C, McComb JG: Benign cerebellar astrocytomas of childhood.

Neurosurgery 30:58-62, 1992

29 Schwartz AM, Ghatak NR: Malignant transformation of benign cerebellar astrocytoma. Cancer 65:333-336, 1990

30. Shapiro K, Katz M: The recurrent cerebellar astrocytoma. Childs Brain 10:168-176, 1983

31. Shin KH, Webster JH: Astrocytoma in children. A review of 79 cases--1960-1976. J Can Assoc Radiol 30:167-169, 1979

32. Undjian S, Marinov M, Georgiev K: Long-term follow-up after surgical treatment of cerebellar astrocytomas in 100 children. Childs Nerv Syst 5:99-101, 1989

33. Ushio Y, Arita N, Yoshimine T, et al: Malignant recurrence of childhood cerebellar astrocytoma: case report. Neurosurgery 21:251-255, 1987

34. Wisoff HS, Llena JF: Glioblastoma multiforme of the cerebellum five decades after irradiation of a cerebellar tumor. J Neurooncol 7:339-344, 1989

35. Zimmerman RA, Bilaniuk LT, Bruno L: Computed tomography of cerebellar astrocytoma. AJR 130:929-933, 1978

Manuscript received November 7, 1996.

Accepted in final form February 21, 1997.

Address reprint requests to: Michael J. Ebersold, M.D., Department of Neurologic Surgery, Mayo Clinic, 200 First Street Southwest, Rochester, Minnesota 55905. 